\title{
Nilai Kearifan Ekologis dalam Mitos Lelipi Selahan Bukit Bagi Masyarakat Desa Tenganan Pegringsingan Kabupaten Karangasem Bali
}

\author{
I Kadek Angga Bayu Aditya', I Gst Ketut Gde Arsana², I Nyoman Suarsana ${ }^{3}$ \\ ${ }^{[123]}$ Prodi Antropologi Fakultas Ilmu Budaya Unud \\ 1 [anggabayuaditya@gmail.com] [2 [s2kjbdyunud@yahoo.com] \\ 3 [inyomansuarsana.58@gmail.com] \\ *Corresponding Author
}

\begin{abstract}
The discourse on the environment is now very hot discussed because of the destruction of forest areas in various countries, including Indonesia. In the life of Tenganan Pegringsingan Village community there is a mysterious mystery myth or Lelipi Selahan Bukit who is believed to guard the forest area of Tenganan Pegringsingan. The existence of these myths indirectly provide a good impact for the environment around for making forest sustainability in the region Tenganan Pegringsingan become awake. This study raises two issues, the first of which values of ecological wisdom contained in the myth of Lelipi Selahan Bukit and the second, how the myth of Lelipi Selahan Bukit in the life of the people of Tenganan pegringsingan Village. This study aims to reveal the myth of Lelipi Selahan Bukit as the ecological wisdom of the local community, in an effort to preserve the forest area. This research uses an ethnoecological approach that depicts the environment as seen by the community under study. This study uses the interpretive theory of Clifford Geertz in expressing local people's thoughts on the myth of Lelipi Selahan Bukit. The research method used is the ethnographic research model that goes into qualitative research by doing observation and interview.The results of this study answer two problems, first reveals the existence of hidden rationality behind the myth of Lelipi Selahan Bukit. The existence of this myth as an ecological wisdom is like a natural fortress that guards the forest area Tenganan Pegringsingan. Second, the emergence of critical thinking from persons who interpret the existence of this myth is not a seed of disunity, this difference of view can enrich the reference of meaning of a phenomenon that occurs in society.
\end{abstract}

Key Words: Tenganan Pegringsingan, Lelipi Selahan Bukit, ecological wisdom.

\section{Latar Belakang}

Wacanamengenai penyelamatan lingkungan mulai hangat diperbincangkan karena rusaknya kawasan hutan di berbagai dunia termasuk Indonesia. Eksploitasi terhadap lingkungan tanpa memperhatikan daya dukung lingkungan itu sendiri merupakan sebuah kegagalan dalam memahami prinsip-prinsip ekologi yang berdampak pada masalah-masalah lingkungan. Ibarat dua sisi mata uang, pada suatu sisi manusia sering kali mengeksploitasi hutan dan sumber daya yang terkandung di dalamnya tanpa memperhatikan daya dukung dan keberlanjutannya, ternyata di sisi lain masih ada masyarakat tradisional dengan kearifan lokalnya mampu 
memanfaatkan dan mengelola lingkungan hutan secara arif seperti yang ada di Desa Tenganan Pegringsingan.

$$
\text { Aspek-aspek kebudayaan }
$$

tradisional seperti sistem pengetahuan, kepercayaan tradisional dapat dipandang sebagai suatu kearifan ekologis yang berguna sebagai mekanisme kontrol dalam pengelolaan lingkungan. Desa Tenganan Pegringsingan merupakan Desa Bali Aga yang terdapat di Kabupatem Karangasem, terdapat sebuah mitos yang berkembang di tengah masyarakatnya tentang keberadaan ular mistis yang dipercaya menjaga kawasan hutan Desa Tenganan Pegringsingan. Mitos tersebut dikenal sebagai Lelipi Selahan Bukit. Fenomena terkait mitos Lelipi Selahan Bukit sejalan dengan pendapat Mac Kinnon yang menyatakan bahwa memang sering dijumpai konsepsi mengenai peranan makhluk halus sebagai pengawas suatu kawasan hutan walaupun secara nyata tidak ada penjaganya (Mac Kinnon dkk, 1990: 63). Kepercayaan akan mitos Lelipi Selahan Bukit menarik untuk dikaji karena mengandung pandangan hidup bagi masyarakatnya. Nilai-nilai kearifan lokal yang terkandung dalam mitos tersebut tanpa disadari telah menjadikannya sebagai suatu kearifan ekologis yang berharga bagi masyarakat Desa Tenganan Pegringsingan dalam menjaga kelesatarian lingkungan hutan.

\section{Pokok Permasalahan}

1. Nilai-nilai Kearifan Ekologis apa yang terkandung dalam mitos Lelipi Selahan Bukit di Desa Tenganan Pegringsingan?

2. Bagaimana makna mitos Lelipi Selahan Bukit bagi masyarakat Desa Tenganan pegringsingan?

\section{Tujuan penelitian}

1. Untuk mengetahui nilai-nilai kearifan ekologis yang terkandung dalam mitos Lelipi Selahan Bukit.

2. Untuk mengetahui makna esensial yang terkandung dalam mitos Lelipi Selahan Bukit serta mengetahui perkembangan makna mitos tersebut dalam kehidupan masyarakatnya.

\section{Metode Penelitian}

a. Lokasi Penelitian

Penelitian ini dilakukan di Desa Tenganan Pegringsingan, Kecamatan Manggis, Kabupaten Karangasem, Provinsi Bali, yang secara mengkhusus memfokuskan sasaran kepada masyarakat Bali Aga yang ada di Desa Tenganan Pegringsingan. Pemilihan Desa Tenganan Pegringsingan didasari oleh adanya kepercayaan masyarakat tentang keberadaan Lelipi Selahan Bukit yang tanpa disadari ternyata memiliki nilai rasionalitas tersembunyi terkait nilai kearifan ekologis dalam pelestarian hutan.

\section{b. Penentuan Informan}

Penentuan informan ditetapkan atas dasar kriteria dan pertimbangan tertentu. Pemilihan informan, terutama informan kunci adalah masyarakat Desa Tenganan Pegringsingan yang dapat merepresentasikan kondisi objek penelitian, baik dalam dimensi umur, status, peran sosial, pengetahuan agama, maupun kategori lainnya.

c. Jenis dan Sumber Data

Data yang dipergunakan dalam penelitian ini bersumber dari hasil observasi lapangan dengan ditunjang referensi yang relevan dengan topik permasalahan yang dibahas.

d. Teknik Pengumpulan dan Analisis Data 
Metode observasi-partisipasi didukung dengan teknik wawancara unstructured akan menghasilkan datadata deskriptif kualitatif (Maryaeni, 2005: 75). Data-data berupa hasil catatan oberservasi dan wawancara, rekaman wawancara, serta studi pustaka akan dikategorikan dalam berbagai kategori mengacu pada pokok bahasan yang telah ditetapkan. Analisis data dilakukan sepanjang penelitian dengan menggunakan pendekatan yang sesuai sebagai kerangka berpikir peneliti.

\section{Hasil dan Pembahasan}

\subsection{Nilai Kearifan Ekologis yang Terkandung Dalam Mitos Lelipi Selahan Bukit}

$\begin{array}{ccr}\text { Mitos } & \text { Lelipi Selahan Buki } \\ \text { merupakan bagian dari } & \text { sistem } \\ \text { kepercayaan } & \text { masyarakat Tenganan }\end{array}$
Pegringsingan. Sistem kepercayaan yang dimiliki oleh masyarakat ini akan senantiasa berpengaruh pada pola pikir dan tingkah laku masyarakat Tenganan Pegringsingan yang nantinya berujung pada cara-cara pengelolaan dan pemanfaatan lingkungan. Lelipi Selahan Bukit tanpa disadari telah menjelma sebagai kearifan ekologi yang menjaga kawasan hutan Tenganan Pegringsingan. Memiliki hasil hutan yang melimpah tentu ada saja segelintir orang yang ingin berniat jahat dan mengambil hasil hutan secara serakah. Pada kepercayaannya apabila ada seseorang yang ingin berniat jahat, atau merusak hutan maka ular ini akan muncul dan mencelakai orang yang berniat jahat tersebut. Stigma inilah yang menimbulkan perasaan takut pada warga setempat apabila melaggar itu. Antropolog Koentajaraningrat menyatakan salah satu cara yang dapat ditempuh untuk mencegah penyimpangan adalah dengan mengembangkan rasa takut dalam jiwa masyarakat (Koentjaraningrat, 1981: 206).
Efek rasa takut akan mitos Lelipi Selahan Bukit apabila seseorang merusak kawasan hutan menghasilkan kebaikan bagi alam sekitarnya, kepercayaan tersebut nyatanya telah menghindari kawasan hutan Tenganan dari alih fungsi lahan, dapat dibayangkan apabila kawasan hutan Tenganan Pegringsingan beralih fungsi menjadi kawasan pemukiman, keseimbangan alam akan menjadi terganggu. Flora dan fauna yang tadinya hidup hidup di hutan akan berkurang keberadaannya karena keberadaan manusia, selain itu kualitas lingkungan yang tadinya terjaga akan rusak dan bisa menyebabkan bencana seperti longsor. Para leluhur masyarakat Tenganan Pegringsingan telah menyadari betapa pentingnya alam bagi kehidupannya saat itu hingga kehidupan generasinya di masa mendatang, dengan adanya cerita seperti mitos Lelipi Selahan Bukit ini secara tidak langsung telah menjadikannya sebagai benteng bagi kawasan hutan Tenganan Pegringsingan agar tetap terjaga kelestariannya.

\subsection{Keterkaitan antara Mitos Lelipi Selahan Bukit dan Tri Hita Karana}

Sejak dahulu orang Bali memang dikenal sangat menghargai lingkungannya. Prinsip-prinsip menghargai lingkungan ini tertuang dalam ajaran agama Hindu yang disebut Tri Hita Karana. Kearifan lokal ini telah menjadi landasan filosofis dalam kehidupan masyarakat Bali yang berlandaskan budaya dan dijiwai Agama Hindu. Secara terminologis Tri Hita Karana berasal dari bahasa Sansekerta. Terdiri dari kata Tri yang berarti tiga, Hita yang berarti sejahtera, dan Karana yang berarti sebab atau penyebab. Apabila dirangkai, maka ketiga kata tersebut berarti tiga hal yang menyebabkan sejahtera. Ketiga hal yang 
dimaksud adalah terwujudnya tiga hubungan harmonis, pertama parahyangan, yaitu hubungan yang harmonis antara manusia dengan tuhanNya. Kedua palemahan, hubungan yang harmonis antara manusia dengan alam dan lingkungan sekitarnya. Ketiga adalah pawongan, hubungan yang harmonis antara manusia kepada sesamanya.

Pengamalan akan falsafah Tri Hita Karana sebenarnya telah dimiliki oleh para leluhur masyarakat Tenganan Pegringsingan, dengan pengetahuan lokal yang dimilikinya para leluhur masyarakat Tenganan Pegringsingan memiliki kontribusi yang baik dalam upaya menjaga kelestarian kawasan hutannya hingga saat ini. Mitos Lelipi Selahan Bukit sebagai kearifan ekologi masyarakat Tenganan Pegringsingan tentu memiliki hubungan yang erat dengan falsafah Tri Hita Karana dalam ajaran Agama Hindu di Bali yang dalam kaitannya dengan alam tentu saja palemahan, yakni hubungan harmonis antara manusia dengan lingkungan alammnya. Leluhur Masyarakat Tenganan Pegringsingan dengan segala kecerdesannya pada masa lampau telah berpikir jauh ke depan mengenai keberlangsungan keadaan lingkungan alammnya. Mitos Lelipi Selahan Bukit merupakan suatu bentuk pengetahuan yang diwariskan secara turun-temurun sampai ke generasi saat ini. Cara ini digunakan oleh para leluhur masyarakat Tenganan Pegringsingan dalam upayanya menjaga kelestarian kawasan hutan. Pada perkembangannya, kepercayaan akan Lelipi Selahan Bukit masih memberikan dampak yang baik sehingga membuat orang-orang tidak berani sembarangan mengeksploitasi hutan.

Alam merupakan bagian yang tak terpisahkan dari kehidupan masyarakat Tenganan Pegringsingan, dari alam lah masyarakatnya dapat memperoleh berbagai kebutuhan sehari-hari, misalnya saja kebutuhan terkait upacara atau ritual. Sebagai Desa Bali Aga yang memiliki adat dan tradisi yang unik kebutuhan akan sarana ritual tentunya sangat sering diperlukan. Kebutuhan-kebutuhan tersebut akan bergantung pada hasil alam yang diperoleh dari kawasan hutan desa Tenganan Pegringsingan yang diantaranya seperti bambu, kayu, buahbuahan, dan lainnya sebagai sarana kebutuhan penunjang berbagai aktivitas upacara dan ritual di Desa Tenganan Pegringsingan.

\subsection{Makna Denotatif dan Konotatif Mitos Lelipi Selahan Bukit}

Mitos Lelipi Selahan Bukit secara denotatif merupakan salah satu bagian dari sistem kepercayaan masyarakat Desa Tenganan Pegringsingan. Lelipi dalam bahasa Bali berarti ular, sementara selahan bukit memiliki arti di sela-sela bukit. Ular diasosiasikan sebagai reptil melata dan memiliki karakteristik atau ciri-ciri fisik (signifier) seperti bertubuh panjang dan memiliki sisik di sekujur tubuhnya. Ular dikenal memiliki senjata alami dalam dirinya yaitu gigitan racun/bisa serta kekuatan melilit lawannya hingga tak berdaya. Terdapat dua jenis ular yaitu yang beracun/berbisa dan ular tidak berbisa. Ular yang dikenal memiliki racun/bisa yang berbahaya diantaranya adalah ular jenis cobra, viper sedangkan ular yang tidak memiliki racun diantaranya adalah ular jenis piton, boa dan anaconda.

Menurut cerita dari orang-orang tua terdahulu yang diwariskan secara lisan kepada anak cucunya hingga kini, ciri-ciri Lelipi Selahan Bukit tersebut ialah memiliki ukuran yang besar, pergerakannya sangat cepat, serta dapat menegakkan kepalanya jika merasa terancam. Dari hasil wawancara yang dilakukan dengan beberapa informan 
diketahui Ciri-ciri fisik ini rupanya hampir sama dengan ular king cobra (Ophiophagus Hannah) yang habitatnya juga dipercaya terdapat di kawasan hutan Desa Tenganan Pegringsingan. Secara konotatif keberadaan Lelipi Selahan Bukit dipandang sebagai makhluk yang dipercayai menjaga hutan di kawasan Tenganan Pegringsingan. Ular secara konotatif diasosiasikan sebagai reptil yang berbahaya, menyeramkan, dan jauh dari kesan jinak. Ular pada umumnya memiliki ciri biologis bertubuh memanjang dan seringkali melingkar, bentuk panjang melingkar tersebut apabila ditelaah secara implisit akan tersirat semacam garis-garis yang berbentuk seperti sebuah peta atau map. Peta disini tentunya dapat dimaknai sebagai wilayah Tenganan Pegringsingan dengan bentuknya yang luas dan membentang harus tetap dijaga kelestariannya. Setiap jengkal wilayah Tenganan merupakan warisan leluhur mereka yang kini menjadi tanggung jawab warga Desa Tenganan Pegringsingan sebagai penerus untuk tetap melestarikannya. Masih ada kaitannya dengan makna yang tersirat akan garis-garis tersebut, ternyata di Desa Tenganan Pegringsingan terdapat sebuah motif kain gringsing yang membentuk garis-garis segi empat tanpa terputus yang bernama motif panggalasu. Masyarakat Desa Tenganan Pegringsingan adalah masyarakat yang religius yang meyakini adanya suatu kekuatan di sekitarnya yang berada di luar diri manusia. Pemikiran manusia tentang sifat-sifat tuhan, wujud para dewa, dan makhluk lainnya yang mendiami alam gaib, yang selanjutnya kesemuanya itu memberikan kehidupan, kebahagiaan dan ketentraman batin. Keinginan untuk mewujudkan pengalaman batinnya, membuka daya cipta manusia untuk mengungkapkan bentuk nyata baik melalui stilirisasi atau stilasi dan abstraksi dari bentuk-bentuk alam, binatang, manusia, dan makhlukmakhluk khayalan sebagai ungkapan rasa bakti kepada Tuhan Yang Maha Kuasa (Ray, 2006: 132).

\subsection{Perkembangan Makna Tentang Lelipi Selahan Bukit}

Seiring berkembangnya era modernitas pemikiran masyarakat pun senantiasa ikut berkembanng, hal ini ditandai dengan peningkatan kognitif dalam pemikiran masyarakat. Dilihat dari kacamata pemikiran rasional mitos Lelipi Selahan Bukit merupakan bentuk proteksi leluhur masyarakat Tenganan Pegringsingan terhadap lingkungan hutannya, dengan adanya mitos Lelipi Selahan Bukit ini diharapakan warga tidak berani sembarangan merusak kawasan hutan. Hutan sebagai salah satu kawasan yang mendukung mata pencarian warga Tenganan Pegringsingan memang sudah selayaknya dijaga keberadaannya. Hutan menyimpan kekayaan alam, cadangan air yang berguna bagi warga desa serta menjaga agar Desa Tenganan Pegringsingan terhindar dari bencana alam seperti longsor. Mitos Lelipi Selahan Bukit juga berfungsi sebagai pengingat bagi warga Tenganan Pegringsingan agar selalu berhati-hati saat masuk ke dalam kawasan hutan, karena di hutan terdapat hewan-hewan yang berbahaya. Hewanhewan seperti ular yang masih menghuni kawasan hutan di Desa Tenganan Pegringsingan dapat dijadikan tolak ukur bahwa kawasan habitanya masih terjaga dengan baik, karena apabila kawasan habitatnya sudah rusak pasti hewanhewan tersebut mulai sulit ditemukan dikawasan tersebut. Keberadaan ular juga dapat dijadikan sinyal-sinyal suatu peristiwa alam bagi masyarakat Desa Tenganan Pegringsingan, tatkala disaat 
ular-ular yang secara mendadak turun meninggalkan kawasan hutan menuju desa disaat terjadi kebakaran atau longsor yang terjadi di kawasan tempat hidupnya. Seperti diketahui hewan seperti ular memiliki sensitifitas yang tinggi terhadap gejala-gejala alam yang terjadi di habitatnya.

\section{Simpulan}

Mitos Lelipi Selahan Bukit adalah salah satu bagian dari kepercayaan masyarakat Tenganan Pegringsingan yang telah menjelma sebagai suatu kearifan ekologi yang berharga bagi kelestarian hutan Tenganan Pegringsingan. Keberadaan mitos Lelipi Selahan Bukit secara tidak disadari membuat kelestarian hutan di kawasan Desa Tenganan Pegringsingan menjadi terjaga. Rasa takut yang muncul pada pemikiran masyarakatnya apabila mengeksploitasi hutansecara serakah dapat menjadi obat mujarab untuk kelestarian hutan di Tenganan Pegringsingan.

\section{Daftar Pustaka}

Koentjaraningrat. 1981. Pokok-Pokok Antropologi Sosial. Jakarta: PT Dian Rakyat.

MacKinnon, Jhon, dkk. 1990. Pengelolaan Kawasan yang Dilindingi di Daerah Tropik. (Hary Harsono Amir, Penerjemah). Yogyakarta: UGM Press.

Maryaeni. 2005. Metode Penelitian Kebudayaan. Jakarta: Bumi Aksara.

Ray, D.A tirta. 2006. Kain Gringsing Dalam Kehidupan Masyarakat Tenganan Pegringsingan Suatu Perspektif Budaya. Program Pascasarjana Univesrsitas Udayana, Denpasar. 